\title{
Study on the Effect of Big Data on Ideological and Political Education and its Application Strategy
}

\author{
Guangxia Su
}

Xi’an Peihua University, Xi’an Shaanxi 710125

Keywords: Big Data; Ideological and Political Education; Effect; Application Strategy

\begin{abstract}
The development of technology promotes the arrival of big data era. Big data has changed the way people live and work. Big data technology brings new opportunities for the scientific and innovative development of ideological and political education at colleges and universities, as well as opportunities for the development of individualized learning for college students. How to effectively apply big data technology to ideological and political education at colleges and universities is an urgent task to be solved. How to deal with the challenge brought by big data to the ideological and political education at colleges and universities is also an urgent problem to be considered and solved by the ideological and political educators at colleges and universities. How to combine the ideological and political education with big data is a topic worthy of further study.
\end{abstract}

\section{Introduction}

The emergence of big data technology marks that our life is entering a data-based era, especially the development of cloud computing technology provides technical support for the collection, storage and analysis of big data, and provides a guarantee for the use of big data technology, so that the personalized needs of people have been met. With the rapid development of modern information technology, the Internet is playing a more and more extensive and convenient role in our life. People always leave a huge amount of data on the Internet and intelligent terminals based on the Internet. We can provide personalized services for people's various needs through the collection and analysis of these data, especially at colleges and universities where network technology is used most fully, all the data left by teachers and students can be collected and analyzed through big data technology to find out the data and information that are useful to education, thus to better reform and innovate teaching methods to achieve zero-distance personalized education for college students, for the country to train specialized personnel in various fields.

\section{The concept and characteristics of big data}

\subsection{The concept of big data}

Big data, called huge amount of information, refers to the massive, high growth rate and diversified information assets that require a new processing model to have greater decision-making power, insight, and process optimization capabilities, in multiple forms. Big data sets collected from many sources. Big data is not a random analysis but to use all the data for analysis.

\subsection{The characteristics of big data}

Big data has the feature of massive data mining, and it must rely on cloud computing distributed processing, distributed databases, cloud storage and / or virtualization technology. Big data has five characteristics that are velocity, variety, value, veracity.

\section{The positive effect of big data on ideological and political education}

Big data has brought great positive effect to ideological and political education, big data can truly reflect the students' spiritual needs and ideological tendencies, and big data is helpful to the 
improvement of the theoretical research system of ideological and political education. Big data can provide data support for evaluating the effect of ideological and political education.

\subsection{Big data can truly reflect the spiritual needs and ideological tendencies of students}

At present, the whole society is in a period of rapid development, the Internet has a great impact on students' thoughts, and the students' thoughts and emotions are very dynamic, Students' ideological and political work has become more difficult. This requires teachers to fully understand the students' spiritual needs and ideological trends, and to analyze what may happen to students through big data, in order to strengthen ideological and political education, reduce the uncertainty of ideological and political aspects of students.

\subsection{Big data is helpful to improve the theoretical research system of ideological and political education}

Big data provides data for the improvement of ideological and political theory curriculum system, to realize the need of curriculum reform, and to enhance the effectiveness of ideological and political education theory curriculum. College students use the network with high frequency, network terminal access to the Internet is relatively single, generally through the campus network interface to connect to the Internet, and college students pay attention to the hot spots and data easy to collect; its network data collection approach is also relatively convenient. The teachers of ideological and political education can excavate and analyze the data, describe the hot issues concerned by college students, ideological needs and other information, and provide reference for ideological and political educators. According to the different characteristics of the educational objects reflected by big data, the ideological and political educators can adjust the educational methods of the ideological and political theory courses, optimize the teaching contents, reform the teaching programs, and make the ideological and political theory courses at colleges and universities alive, to enhance the affinity and pertinence of ideological and political theory, promote the realization of teaching objectives.

\subsection{Big data can provide data support for the evaluation of the effects of ideological and political education}

Due to the complexity of the changes in human thoughts, there is a latent period of ideological change. At the same time, the new social environment has brought a lot of new situations and problems. It is difficult to determine the main causes and interference factors of ideological and political education objects in traditional ways, which makes the evaluation structure of ideological and political education effect complex and difficult to control. Through the network comment big data excavates, unifies the network terminal data to obtain the group distinction, can not only obtain the social crowd overall value view tendency, but also can show a certain area social member's thought viewpoint concretely. Therefore, we can get the corresponding trend of ideological change of social members, by comparing and analyzing the data of hot events, thus providing data support for the comprehensive evaluation of the effect of ideological and political education.

\section{The negative effect of big data on ideological and political education}

Big data has also brought a lot of negative effects to the ideological and political education work. The ideological and political education presents a digital existence, the ideological and political education falls into ethical dilemma, and the challenges of ideological and political education work increase.

\subsection{The ideological and political education presents data existence}

The main body of ideological and political education at schools is surrounded by various kinds of data, which weakens the permeability and effectiveness of its education to some extent. The effect of work is getting weaker and weaker. Secondly, the existence of data has an impact on the thought of college students. The non-mainstream values and a large amount of false bad information 
In the west, big data has alienated the values, behavior patterns and physical and mental development of college students to a certain extent, greatly increased the network ideological and political education difficulty. Thirdly, the existence of data makes the pressure of network public opinion increase in colleges and universities, big data makes the information spread quickly, and it is open and transparent. It is easy to set off a frenzy of network public opinion, which has a great effect on students.

\subsection{The ideological and political education falls into ethical dilemmas}

The most colleges and universities can use their own information technology means, such as university students' online log retention, cloud basic platform, students' dynamic early warning system and so on, which can obtain the relevant data information of college students in all directions, which can provide a perfect data collection environment for data analysis and research to a certain extent. But these data may cause ethical dilemmas, may violate students' personal factors and hurt students' self-esteem.

\subsection{The challenge of ideological and political education increases}

Big data makes ideological and political education work in a new environment. The current school ideological and political workers have many years of mature and formative education and teaching experience, understanding of the concept of big data, as well as the use of new technologies and methods brought about by big data, are not very familiar with or cannot be proficient in the short term. This will inevitably affect big data's ideological and political education effect and value. Technical problems are the thorniest.

\section{Big data's application strategy in ideological and political education}

Big data usually needs to go through three programs: data collection, data mining, and data analysis.

\subsection{The thought of ideological and political education needs to be diversified}

The effect of big data on the subject of network ideological and political education is mainly reflected in the change of thinking mode, that is, the subject from relevance to causality, new thinking develops and innovates and moves towards a diversified mode of thinking. The complicated and inextricable connections that occur in the process of data transmission need the network ideological and political educators in colleges and universities to have the relevant thinking. The real value of the data can be excavated through the control of the relevance of data, and the phenomenon of "information cocoon room" which appears because of the fragmentation of information can be avoided, and then the accurate prediction and dissemination of information can be carried out.

\subsection{To Explore big data capturing students' demand for ideological and political education}

It is necessary to analyze the individual demands of college students. A large amount of data is used as a microscope to observe students' thoughts, and real-time tracking and monitoring of real-time and related data of online learning is carried out by using the cloud base platform and the network log retention and other devices, so as to pay attention to the mouse retention time of the online module. The data of the focus topic, the participation and accuracy of classroom discussion are used to analyze the characteristics of individual students' thoughts and behaviors, the demands of teaching content and the acceptance of teaching difficulties and so on. Secondly, ideological and political educators carry out individualized teaching through analysis, prediction and adjustment. According to the demand of small scale customization, the difficulty of teaching content and teaching order are adjusted, and combined with student library to recommend customized learning strategy, finally guide students to adjust themselves. 


\subsection{To strengthen data analysis to provide individualized method of ideological and political education}

Big data's individualized thinking has higher value characteristic, which awakens massive data in database from time dimension and space dimension. Combining rational thinking with deep emotional analysis, human nature and semantic analysis, the object of study in the characteristics of preferences, emotional characteristics, and even about to implement the characteristics of behavior to be accurately characterized, this is the success of the business field. It is necessary to trace the data of college students' behavior habit, study motivation, study habit and so on, according to the analysis of the data, to provide the individualized method of ideological and political education for college students.

\subsection{To make use of big data to support ideological and political education}

The rational and perceptual data of students in the field of network ideological and political education in schools, ensure the objectivity of the data to the greatest extent, and then provide scientific decision making. Firstly, the quantitative research paradigm should be used to promote the innovation of the combination of qualitative and quantitative research in network ideological and political education. Secondly, some enterprises and media out of school have grasped the massive data of college students' life and study, and have strong ability of data analysis; we can analyze the data legally and legally with the help of the force of outside school, and study its law. Thirdly, due to the bottleneck of team and technology, it is necessary to set up a professional data analysis team in colleges and universities with information center and student work department, and can also outsource services. Fourth, make the system of data security, protect students' privacy in using data as far as possible, and do a good job of keeping information confidential. Finally, the database and big data platform for data query, analysis and other fields are built to provide platform guarantee for quantification.

\section{Conclusion}

All in all, big data is a new resource, which not only brings influence to ideological and political education at colleges and universities, but also brings opportunities to ideological and political education at colleges and universities. Ideological and political education at colleges and universities must establish and strengthen big data consciousness, give full play to big data technology and advantages, actively explore and innovate the contents and methods of ideological and political education, and constantly adjust the connection between ideological and political education and big data background. We can effectively improve the effectiveness of ideological and political education in big data era, to strengthen the pertinence and foresight of ideological and political education at colleges and universities.

\section{References}

[1] Guimei He. On the Influence and Opportunity of Big Data on Ideological and Political Education at Colleges and Universities [J]. Journal of Wuhan University of Business. 30 (2): 89-92.

[2] Yi-zhao Chen. On Big data's Application in Ideological and Political Education at Colleges and Universities [J]. Science and Technology Outlook, 27 (28): 16-16

[3] Qian Zhu. On a Probe into the Ideological and Political Education of Graduate Students in Big Data Era [J]. Journal of Higher Education, 2017 (16): 169-172.

[4] Jinyu Hu, Biaohong Hu, Bingyan He. A logical Discussion on the Evaluation Mechanism of Postgraduate Ideological and Political Education in Big Data Era [J]. Study Higher Education in Heilongjiang, 2017 (8): 139-141.

[5] Yan Bai, Quanzhong Tang. On the Actual Effect of Ideological and Political Education at Colleges and Universities in Big data era [J]. Journal of Heilongjiang Institute of Education, 2016 
(6): 77-79.

[6] Xie Yingying. On the Path of Improving the Permeability and Effectiveness of Ideological and Political Education at Colleges and Universities in Big Data Era [J]. Journal of North China University of Electric Power: Social Sciences, 2016, No.100 (2): 128-131. 